\title{
Study on Urban Family Consumption of Minor Children in Weihai Based on ELES Model
}

\author{
Yuqing Shen \\ Business School, Shandong University, Weihai, 264209, China
}

\author{
Keywords: Two-child family, Urban family, ELES model, Consumption structure
}

\begin{abstract}
In order to investigate the impact of baby boom on urban family consumption in Weihai, the questionnaire survey was carried out to obtain the family consumption data of food, clothing, health care, household articles, cultural and educational entertainment. Using the ELES model to process the data, the marginal propensity to consume, basic consumption expenditure and actual expenditure, demand income elasticity and price elasticity for family consumption in Weihai were obtained. The family consumption characteristics of the family in Weihai were analyzed, and some suggestions about urban family consumption were put forward as well. The study shows that the consumption tendency of the family with two-children is greater than that of one-child; however, in real life, the economic burden of the two-child families has increased so that the life quality has been affected to some extent.
\end{abstract}

\section{Introduction}

In order to solve the problems of population structure, social support, economic downturn and others, China has successively launched the two-child policy in the family of both the father and mother are the only child, the two-child policy in the family of only the father or mother is the only child, and the two-child policy in every family from 2011 to 2016. In the long run, the two-child policy has a profound impact on China's economy. It will not only help to supplement the new labor force for the future, reduce production costs, but also bring huge new population consumption and industry opportunities. This year is the second year of the comprehensive two-child policy implementation. There is a wave of two-children in all parts of the country. In order to study the impact of the two-child policy on the urban household consumption in the third-tier cities and towns in the coastal areas of China, the author's team visited the Weihai city of Shandong province. Through the investigation and collection of online questionnaire, more than 1300 minor children of urban household data in nearly a year of income and consumption expenditure has been collected. Using the ELES model to process the data, the marginal propensity to consume, basic consumption expenditure and actual expenditure, demand income elasticity and price elasticity for family consumption in Weihai were obtained. By comparing the one-child family with the two-child family, this paper discusses the influence of the two-children on the consumption structure of the urban family in Weihai.

\section{Household Consumption Survey in Urban Family of Weihai}

The object of this survey is the children of the urban families in Weihai, that is, one-minor-child family and two-child family with at least a minor child. Paper questionnaires were sent to primary and secondary school students, children or children's family members through primary and secondary school, kindergarten head teacher or maternal and station of health care of women and children, hospital pediatric director, requiring parents / family members to return questionnaires within a certain period. All the paper questionnaires were finally uniformly reclaimed.

A total of 1400 copies of paper questionnaires were distributed in this research. The reclaimed paper and network questionnaires were more than 1300 copies, and the valid questionnaires were more than 1200 copies. This paper analyzes the influence of the second child on family consumption in Weihai, focusing on five kinds of consumption, including food, education and entertainment, 
clothing, medical care and household goods.

\section{ELES Model}

The expression model of ELES model is shown as follows:

$$
\mathrm{V}_{\mathrm{i}}=\mathrm{p}_{\mathrm{i}} \mathrm{q}_{\mathrm{i}}=\mathrm{p}_{\mathrm{i}} \mathrm{r}_{\mathrm{i}}+\beta_{\mathrm{i}}\left(I-\sum_{\mathrm{i}=1}^{\mathrm{n}} \mathrm{p}_{\mathrm{i}} \mathrm{r}_{\mathrm{i}}\right) \mathrm{i}=1,2, \ldots \mathrm{n}
$$

In the above formula, Vi stands for the consumption expenditure of the commodity of the type i. I is the Per capita income level. In this paper, it is the average household income. pi and qi are respectively the I commodity prices and per capita (average household demand); ri stands for the basic demand of the consumption per capita (average household); $\beta \mathrm{i}$ is the marginal propensity to consume of the commodity $i$, that is, the consumer income to buy all kinds of goods beyond the basic needs of more than the purchase of additional i the proportion of commodities for volume; piri is the basic demand expenditure of the commodity i. $\sum_{i=1}^{n} p_{i} r_{i}$ is the total expenditure for the basic demand.

We assume

$$
\alpha_{\mathrm{i}}=\mathrm{p}_{\mathrm{i}} \mathrm{r}_{\mathrm{i}}-\beta_{\mathrm{i}} \sum_{\mathrm{i}=1}^{\mathrm{n}} \mathrm{p}_{\mathrm{i}} \mathrm{r}_{\mathrm{i}}
$$

$$
\mathrm{i}=1,2, \ldots \mathrm{n}
$$

The forumula (1) can be transformed into:

$$
\mathrm{V}_{\mathrm{i}}=\alpha_{\mathrm{i}}+\beta_{\mathrm{i}} I+\mathrm{u}_{\mathrm{i}} \quad \mathrm{i}=1,2, \ldots \mathrm{n}
$$

In the formula, $\mathrm{u}_{\mathrm{i}}$ is the residual term of disturbance term; $\alpha_{\mathrm{i}}$ and $\beta_{\mathrm{i}}$ are the parameters to be estimated. $\hat{\alpha}_{\mathrm{i}}$ and $\hat{\beta}_{\mathrm{i}}$ can be estimated by least square method of the consumption section data.

Therefore, we have:

$$
\begin{array}{ll}
\sum_{\mathrm{i}=1}^{\mathrm{n}} \mathrm{p}_{\mathrm{i}} \mathrm{r}_{\mathrm{i}}=\sum_{\mathrm{i}=1}^{\mathrm{n}} \alpha_{\mathrm{i}} /\left(1-\sum_{\mathrm{i}=1}^{\mathrm{n}} \beta_{\mathrm{i}}\right) & \mathrm{i}=1,2, \ldots \mathrm{n} \\
\mathrm{p}_{\mathrm{i}} \mathrm{r}_{\mathrm{i}}=\alpha_{\mathrm{i}}+\beta_{\mathrm{i}} \sum_{\mathrm{i}=1}^{\mathrm{n}} \alpha_{\mathrm{i}} /\left(1-\sum_{\mathrm{i}=1}^{\mathrm{n}} \beta_{\mathrm{i}}\right) & \mathrm{i}=1,2, \ldots \mathrm{n}
\end{array}
$$

When we do the resident (family) consumption elasticity analysis, we often need to know the parameters of the demand income elasiticity and the natural price elasiticity. The expression of the demand income elasiticity is: $\eta_{\mathrm{i}}=\partial \mathrm{v}_{\mathrm{i}} / \partial \mathrm{I} \cdot \frac{I}{\mathrm{~V}_{\mathrm{i}}}=\beta_{\mathrm{i}} \cdot \frac{I}{\mathrm{~V}_{\mathrm{i}}}$. The expression of the natural price elasiticity is $\eta_{\mathrm{ii}}=\left(1-\beta_{\mathrm{i}}\right) \frac{\mathrm{P}_{\mathrm{i}} \mathrm{r}_{\mathrm{i}}}{\mathrm{V}_{\mathrm{i}}}-1$.

\section{ELES Analysis of Urban Family Consumption of Minor Children in Weihai}

\subsection{Average Household Expenditure of Actual Consumption}

The average consumption expenditure Vi of five categories of goods in Table 1 shows that Food $>$ Cultural and entertainment items $>$ Clothing $>$ Medical Care $>$ Household articles in both one-child family and two-child family. Compared with the Vi data of the average real consumption expenditure of one-child and two-child family in Table 1, we can see that the actual consumption expenditure of five kinds of goods in two-child families is higher than that of one-child family in Vi. The sum of the annual average actual spending of the five types in two-child family of goods is 44230 Yuan, 3736 Yuan more than one-child family. These 3736 Yuan was mainly from the children's toys, entertainment and other aspects of development. It also includes child health care, child's clothing and 
child's products consumption contribution. It is the economic cost of real life in Weihai two-children family rearing two pay treasure, brings certain economic pressure to the family of two-children. It is worth noting that, only one entertainment, two-child family's actual consumption expenditure is 6008 Yuan, 1274 Yuan higher than that of one-child family, which shows that the two-child family generally pay attention to cultural and entertainment investment of the second child.

Table 1. Parameter estimation of Urban Family Consumption of Minor Children in Weihai

\begin{tabular}{|c|c|c|c|c|c|c|}
\hline Item & Family type & $\alpha_{i}$ & $\beta_{\mathrm{i}}$ & $\begin{array}{c}\mathrm{V}_{\mathrm{i}} \\
\text { (Yuan) }\end{array}$ & $\begin{array}{c}\mathrm{P}_{\mathrm{i}} \mathrm{r}_{\mathrm{i}} \\
\text { (Yuan) }\end{array}$ & $\mathrm{R}^{2}$ \\
\hline \multirow{2}{*}{ Food } & One-child & 6644.715 & 0.2224 & 28740 & 18482 & 0.804 \\
\hline & Two-child & 7197.46 & 0.2260 & 29651 & 22564 & 0.9111 \\
\hline \multirow{2}{*}{$\begin{array}{l}\text { Cultural and } \\
\text { entertainment } \\
\text { items }\end{array}$} & One-child & 2127.51 & 0.0262 & 4734 & 3524 & 0.7960 \\
\hline & Two-child & 2134.95 & 0.0390 & 6008 & 4786 & 0.8217 \\
\hline \multirow{2}{*}{ Health care } & One-child & 822.625 & 0.0056 & 1378 & 1120 & 0.8529 \\
\hline & Two-child & 1110.87 & 0.0091 & 2019 & 1732 & 0.7919 \\
\hline \multirow{2}{*}{ Clothing } & One-child & 259.055 & 0.0407 & 4301 & 2424 & 0.7852 \\
\hline & Two-child & 620.54 & 0.0408 & 4668 & 3390 & 0.8183 \\
\hline \multirow{2}{*}{$\begin{array}{c}\text { Household } \\
\text { articles }\end{array}$} & One-child & 727.6 & 0.0061 & 1338 & 1054 & 0.7218 \\
\hline & Two-child & 720.91 & 0.0117 & 1883 & 1516 & 0.8486 \\
\hline \multirow{2}{*}{ Sum } & One-child & 10581.51 & 0.3011 & 40494 & 26606 & -- \\
\hline & Two-child & 11784.73 & 0.3266 & 44230 & 33991 & -- \\
\hline
\end{tabular}

Table 2. Marginal consumption share and Basic consumption expenditure in two types of urban family

\begin{tabular}{ccccccc}
\hline Item & Family Type & Food & $\begin{array}{c}\text { Cultural and } \\
\text { entertainment } \\
\text { items }\end{array}$ & $\begin{array}{c}\text { Health } \\
\text { care }\end{array}$ & Clothing & $\begin{array}{c}\text { Household } \\
\text { articles }\end{array}$ \\
\hline $\begin{array}{c}\text { Marginal } \\
\text { consumption share }\end{array}$ & One-child & 0.739 & 0.087 & 0.019 & 0.135 & 0.020 \\
Two-child & 0.692 & 0.119 & 0.028 & 0.125 & 0.036 \\
$\begin{array}{c}\text { Basic consumption } \\
\text { expenditure (Yuan) }\end{array}$ & One-child & 18482 & 3524 & 1120 & 2424 & 1054 \\
$\begin{array}{c}\text { Ratio of Basic } \\
\text { consumption } \\
\text { expenditure to }\end{array}$ & One-child & 22564 & 4786 & 1732 & 3390 & 1516 \\
Actual Consumption & Two-child & 0.643 & 0.744 & 0.812 & 0.563 & 0.788 \\
\hline
\end{tabular}

\subsection{Marginal Propensity to Consume of Commodities}

Table 1 shows that the sum of the marginal propensity to consume of the five types of consumption in the two-child families is about 0.33, that is, 33 Yuan for each increase of 100 Yuan income, and 67 Yuan for the five types of goods, while the other is used to increase storage or other consumption. In contrast, the sum of the marginal propensity to consume of five types of children in on- child family is 0.30 , less than 0.33 of the two-child family; in fact, the marginal propensity to consume of all five types of consumption in one-child family is less than two-child family. This shows that, compared with the one-child family, income increases for the two-child families in terms of consumption are more pulling power.

The marginal consumption share of Table 2 reflects what consumption direction will be more used after the increase of income of one-child and two-child family. According to the data, the marginal consumption share $(0.739,0.692)$ of one-child and two-child families were the largest in the ranking of the marginal consumption share of five types of commodities, and the marginal consumption share 
of clothing $(0.135,0.125)$ was followed. This shows that eating and clothing are the top priorities and the custody of minor children of the family. After the increase of the family income, one-child and two-child will give priority to additional spending on food and clothing.

\subsection{Basic Consumption Expenditure}

Table 2 gives the basic consumption expenditure level of one-child and two-child families in Weihai, and the sum is the total expenditure of the basic consumption of the five types of household goods in the year. Table 2 shows, in the past year, basic consumer spending Weihai two-children family of five types of goods is 33991 Yuan, accounting for the $76.8 \%$ in the average expenditure of actual consumption of 44230 Yuan. The three data were significantly greater than the corresponding data to one-child family: 26606 Yuan, 40494 Yuan and 65.7\%. This shows that the two-child families to maintain their basic consumption of five categories of goods, each year more than the average cost of spending more than 7300 Yuan per child family. Note: in the average annual actual consumption expenditure of the five categories of goods, two-children are 3736 Yuan higher than the one-child family. The annual disposable income level of one-child family (95570 Yuan) is only slightly lower than that of the two-child family (95830 Yuan).

It can be found that the proportions of five kinds of basic consumer goods in one-child family to the expense of actual expenditures were less than two-child families. It means that a child family has more proportion of the expenditure for the enjoyment of consumption, and non-rigid basic consumer demand. The quality of life of one-child family is better than that of the two-child family.

\subsection{Demand Income Elasiticity and Natural Price Elasiticity}

Table 3 shows that the income elasticity of clothing and food of the one-child family and two-child family are large and the income effect are stronger, while the income elasticity value of health care is small, and the sensitivity to income change is low.

Table 3. Demand income elasiticity of five categories of commodities in One-child and two-child families

\begin{tabular}{lccccc}
\hline $\begin{array}{l}\text { Family } \\
\text { Type }\end{array}$ & Food & $\begin{array}{c}\text { Cultural and } \\
\text { entertainment } \\
\text { items }\end{array}$ & $\begin{array}{c}\text { Health } \\
\text { care }\end{array}$ & Clothing & $\begin{array}{c}\text { Household } \\
\text { articles }\end{array}$ \\
\hline One-child & 0.766 & 0.548 & 0.401 & 0.936 & 0.454 \\
Two-child & 0.757 & 0.644 & 0.449 & 0.867 & 0.617 \\
\hline
\end{tabular}

Table 4. Natural price elasiticity of five categories of commodities in One-child and two-child families

\begin{tabular}{lccccc}
\hline $\begin{array}{l}\text { Family } \\
\text { Type }\end{array}$ & Food & $\begin{array}{c}\text { Cultural and } \\
\text { entertainment } \\
\text { items }\end{array}$ & $\begin{array}{c}\text { Health } \\
\text { care }\end{array}$ & Clothing & $\begin{array}{c}\text { Household } \\
\text { articles }\end{array}$ \\
\hline One-child & -0.643 & -0.294 & -0.196 & -0.482 & -0.221 \\
Two-child & -0.583 & -0.265 & -0.157 & -0.332 & -0.213
\end{tabular}

The elastic data of Table 4 has the following characteristics: first, the price elasticity values of all commodities in one-child and two-child family are all negative, indicating that the commodity price and demand are negative linear correlation. Second, and the two basic consumer demands of food and clothing are influenced by price changes. The price volatility will be firstly influence the food and clothing problem. Third, when the household price of two-child family changes, the influence of the demand is weak.

\section{Conclusion}

Through the investigation, we collected the income and consumption expenditure data of urban family of minor children in Weihai. Based on the data, we used the ELES model to obtain the parameters of marginal propensity to consume of commodities, basic consumption expenditure, 
average actual expenditure, demand income elasiticity and natural price elasiticity of the one-child and two-child families in Weihai. By comparing the data of one-child and two-child families, this paper discussed the consumption characteristics of urban families of the minor children in Weihai, and the influence of the two-children on the urban household consumption in Weihai. The study shows that the consumption tendency of children in Weihai's two-child families is generally greater than that of one-child family; compared with one-child family, the increase of two-children's family income has more stimulating power to promote their consumption. On the other hand, in the real life, the two-child families pay more economic cost for raising their children. The burden is heavier, and the living standard and quality of life are also affected.

\section{Acknowledgement}

The paper was financially supported by Team Project of Social Practice of Business School of Shandong University.

\section{References}

[1] C. Liuch and R. Williams. Consumer Demand Systems and Aggregate Consumption in the U.S.A.: An Application of the Extended Linear Expenditure System [J].Canadian Journal of Economics, 1975, 8 (1):49-66

[2] R.Klein, H..Rubin. A Constant Utility Index of Cost of Living [J]. Review of Economic Studies,1950(18):84-87.

[3] Cai Yongsheng, Li Jing. Research on Consumption Structure Change of Urban Residents with ELES Model [J]. Journal of Chongqing Institute of Technology (Natural Science), 2009, 23(4): 34-38.

[4] Jiang Miao, He Li. A Study on the Change of China's Urban Residents' Consumption Strueture-An Empirical Analysis Based on ELES Model [J]. Research on Economies and Management, 2013(6): 21-26. 